\title{
Abortion and breast cancer: a case-control record linkage study
}

\author{
M J Goldacre, L M Kurina, V Seagroatt, D Yeates
}

There is controversy about whether interruption of pregnancy, particularly if it is induced rather than spontaneous, increases the risk of breast cancer. Individual studies, and reviews summarising them, have given conflicting results. ${ }^{12}$ Recent guidelines from the UK Royal College of Obstetricians and Gynaecologists (http://www.rcog.org.uk) state that the evidence is inconclusive but that, when only those studies least susceptible to bias are considered, induced abortion does not seem to increase risk.

Most studies of this association have been case-control interview studies. An important and much discussed consideration is whether such studies are inherently subject to reporting bias - that women with breast cancer may be more likely than control women to tell the interviewer if they have had an induced abortion when questioned about their reproductive history. ${ }^{3-5}$ If there are systematic reporting biases in interview studies, neither pooling of data across studies in meta-analysis nor further similar studies will eliminate their effects. The overall odds ratio calculated in Brind's meta-analysis relied exclusively on data from 21 case-control studies. ${ }^{1}$ By contrast, prospective cohort studies and studies based on linkage of independent records cannot be influenced in this way by reporting bias. However, only three such studies have been published. $^{6-8}$

\section{Methods}

We undertook a nested case-control study using linked, anonymised data from the Oxford record linkage dataset. Our methods for studying disease associations in this way are described in detail elsewhere. ${ }^{9}$ Data were analysed from 1968-1998 (that is, after the Abortion Act of 1967 which liberalised abortion) and comprise statistical abstracts of records of National Health Service (NHS) hospital admissions (including day cases) and death certificates. "Cases" were records of women with breast cancer ( $n=28$ 616). "Controls" were records of women with a wide range of other, mainly minor, medical and surgical admissions ( $\mathrm{n}=325$ 456). Records were analysed, comparing cases and controls, to identify prior hospital admissions coded as induced abortion, spontaneous abortion, or abortion unspecified as induced or spontaneous. It was common for abortions to be coded without qualification of whether they were induced or spontaneous. Cases and controls were stratified by age (in five year bands), year of occurrence of case or control event, and place of residence. Limited stratification for social class was possible although the recording of social class data was incomplete.

\section{Results}

Overall, previous abortion was slightly less common in women with breast cancer than in controls (table 1). We wondered if the lower rate might result from confounding with social class; but it was found in each social class stratum. The ratio of observed to expected cases did not increase over time either for all abortions or for induced abortions, as would be expected if abortions were a cause of breast cancer. When induced abortions were compared with other abortions, the ratios of
Unit of Health-Care

Epidemiology,

Department of Public

Health, University of

Oxford, Institute of

Health Sciences, Old

Road, Oxford

OX3 7LF, UK

Correspondence to: Dr Goldacre

(michael.goldacre@

dphpc.ox.ac.uk)

Accepted for publication 21 November 2000

Table 1 Prior abortion in women with breast cancer: observed numbers of women with breast cancer and prior abortion, expected numbers, the ratio of observed to expected, and $95 \%$ confidence intervals

\begin{tabular}{|c|c|c|c|c|c|}
\hline & & $\begin{array}{l}\text { Interval between exposure } \\
\text { and cancer }\end{array}$ & Observed & Expected & $O / E(95 \% C I)$ \\
\hline Prior abortion (all) ${ }^{\star}$ & Breast cancer & $\begin{array}{l}\text { all time intervals } \\
0-4 \text { years } \\
5-9 \text { years } \\
10-14 \text { years } \\
15+\text { years }\end{array}$ & $\begin{array}{l}564 \\
97 \\
121 \\
132 \\
214\end{array}$ & $\begin{array}{l}643.3 \\
110.9 \\
139.3 \\
151.8 \\
248\end{array}$ & $\begin{array}{l}0.88(0.81,0.95) \ddagger \\
0.88(0.71,1.07) \\
0.87(0.72,1.04) \\
0.87(0.73,1.03) \\
0.86(0.75,0.99)\end{array}$ \\
\hline Prior induced abortion $\dagger$ & Breast cancer & $\begin{array}{l}\text { all time intervals } \\
0-4 \text { years } \\
5-9 \text { years } \\
10-14 \text { years } \\
15+\text { years }\end{array}$ & $\begin{array}{l}300 \\
55 \\
70 \\
71 \\
104\end{array}$ & $\begin{array}{l}362.6 \\
69.1 \\
82.5 \\
86.4 \\
127.9\end{array}$ & $\begin{array}{l}0.83(0.74,0.93) \ddagger \\
0.80(0.60,1.04) \\
0.85(0.66,1.07) \\
0.82(0.64,1.04) \\
0.81(0.66,0.98)\end{array}$ \\
\hline Prior spontaneous abortion $\dagger$ & Breast cancer & $\begin{array}{l}\text { all time intervals } \\
0-4 \text { years } \\
5-9 \text { years } \\
10-14 \text { years } \\
15+\text { years }\end{array}$ & $\begin{array}{l}41 \\
12 \\
11 \\
13 \\
5\end{array}$ & $\begin{array}{l}44.6 \\
14.8 \\
12 \\
10.4 \\
7.5\end{array}$ & $\begin{array}{l}0.92(0.66,1.25) \\
0.81(0.42,1.42) \\
0.92(0.46,1.64) \\
1.25(0.67,2.14) \\
0.67(0.22,1.56)\end{array}$ \\
\hline
\end{tabular}

^Includes records of abortion coded as "induced" (codes 635-6 in the International Classification of Diseases (ICD) 9th Revision) or "spontaneous" (ICD9 634) and includes records of abortion without further specification (ICD9 637); and breast cancer (ICD9 174). Equivalent codes used in ICD8 and ICD10. †Includes records of women with abortion coded as "induced" or "spontaneous" whether or not the woman also had records in the other categories of abortion. $¥$ Ratio of $\mathrm{O} / \mathrm{E}$ for induced abortion to that for other abortion (that is, all minus induced): 0.88 (95\% CI $0.74,1.04)$. 
observed to expected cases were not significantly different overall (table 1) or at individual time periods.

\section{Discussion}

None of the cohort or record linkage studies have shown a significant increase in breast cancer risk after exposure to induced abortion. ${ }^{6-8}$ Like the Swedish linkage study ${ }^{6}$ we found a slightly lower than expected rate of abortion before breast cancer. The most probable explanation for this is confounding with other reproductive or lifestyle variables outside the scope of our study. For example, if women who have abortions have more pregnancies and/or earlier pregnancies than other women, a slightly reduced risk of breast cancer might follow. Our data on abortions are substantially incomplete because they only include women admitted to hospital, only include those in the care of the National Health Service, and only in the time and area covered by the study. However, our use of control groups that are closely matched for these factors means that the relative rates of occurrence, comparing cases and controls, should be unbiased in these respects. Furthermore, our study includes appreciable numbers of women with an interval of 15 years or more between abortion and cancer; and the confidence intervals are small. The fact that the relative rates did not increase with increasing time intervals between abortion and breast cancer indicates that interruption of pregnancy, whether spontaneous or induced, does not increase the risk of breast cancer.

Funding: The Unit of Health-Care Epidemiology is funded by the South East Regional Office of the National Health Service Executive.

Conflicts of interest: none.

1 Brind J, Chinchilli VM, Severs WB, et al. Induced abortion as an independent risk factor for breast cancer: a comprehensive review and meta-analysis. 7 Epidemiol Community Health 1996;50:481-96.

2 Wingo PA, Newsome K, Marks JS, et al. The risk of breast cancer following spontaneous or induced abortion. Cancer Causes Control 1997;8:93-108.

3 Lindefors-Harris BM, Eklund G, Adami HO, et al. Lindefors-Harris BM, Eklund G, Adami HO, et al.
Response bias in a case-control study: analysis utilizing comparative data concerning legal abortions from two independent Swedish studies. Am f Epidemiol 1991;134: independ $1003-8$.

4 Tang MTC, Weiss NS, Daling JR, et al. Case-control differences in the reliability of reporting a history of induced abortion. Am F Epidemiol 2000;151:1139-43.

5 Rookus MA. Invited commentary: reporting bias in case-control studies on induced abortion and breast cancer. Am F Epidemiol 2000;151:1144-7.

6 Lindefors-Harris BM, Eklund G, Meirik O, et al. Risk of cancer of the breast after legal abortion during first trimester: a Swedish register study. BMF 1989;299:1430-2.

7 Melbye $\mathrm{M}$, Wohlfahrt J, Olsen $\mathrm{JH}$, et al. Induced abortion and the risk of breast cancer. N Engl f Med 1997;336:81-5.

8 Lazovich D, Thompson JA, Mink PJ, et al. Induced abortion and breast cancer risk. Epidemiology 2000;11:76-80.

9 Goldacre M, Kurina L, Yeates D, et al. Use of large medical Goldacre $M$, Kurina $\mathrm{L}$, Yeates $\mathrm{D}$, et al. Use of large medical
databases to study associations between diseases. QfM 2000;93:669-75. 